\title{
Reduction of Lung Inflammation, Oxidative Stress and Apoptosis by the PDE4 Inhibitor Roflumilast in Experimental Model of Acute Lung Injury
}

\author{
P. KOSUTOVA ${ }^{1}$, P. MIKOLKA ${ }^{1}$, M. KOLOMAZNIK ${ }^{1}$, S. BALENTOVA ${ }^{2}$, M. ADAMKOV ${ }^{2}$, \\ A. CALKOVSKA ${ }^{1}$, D. MOKRA ${ }^{1}$ \\ ${ }^{1}$ Biomedical Center Martin and Department of Physiology, Jessenius Faculty of Medicine in \\ Martin, Comenius University in Bratislava, Slovakia ${ }^{2}$ Department of Histology and Embryology, \\ Jessenius Faculty of Medicine in Martin, Comenius University in Bratislava, Slovakia
}

Received March 6, 2018

Accepted September 12, 2018

\section{Summary}

Damage of alveolar-capillary barrier, inflammation, oxidative injury, and lung cell apoptosis represent the key features of acute lung injury (ALI). This study evaluated if selective phosphodiesterase (PDE)-4 inhibitor roflumilast can reduce the mentioned changes in lavage-induced model of ALI. Rabbits with ALI were divided into 2 groups: ALI without therapy (A group) and ALI treated with roflumilast i.v. ( $1 \mathrm{mg} / \mathrm{kg} ; A+R$ group). One group of healthy animals without ALI served as ventilated controls ( $C$ group). All animals were oxygen-ventilated for further $4 \mathrm{~h}$. At the end of experiment, total and differential counts of cells in bronchoalveolar lavage fluid (BALF) and total and differential counts of white blood cells were estimated. Lung edema formation was assessed from determination of protein content in BALF. Pro-inflammatory cytokines (TNFa, IL-6 and IL-8) and markers of oxidation (3-nitrotyrosine, thiobarbituricacid reactive substances) were detected in the lung tissue and plasma. Apoptosis of lung cells was investigated immunohistochemically. Treatment with roflumilast reduced leak of cells, particularly of neutrophils, into the lung, decreased concentrations of cytokines and oxidative products in the lung and plasma, and reduced lung cell apoptosis and edema formation. Concluding, PDE4 inhibitor roflumilast showed potent anti-inflammatory actions in this model of ALI.

\section{Key words}

Roflumilast • Lung injury • Inflammation • Oxidative stress • Apoptosis

\section{Corresponding author}

D. Mokra, Biomedical Center Martin and Department of Physiology, Jessenius Faculty of Medicine in Martin, Comenius University in Bratislava, Mala Hora 4C, SK-03601 Martin, Slovakia. E-mail: mokra@jfmed.uniba.sk

\section{Introduction}

Acute lung injury (ALI) is an acute lung disorder, characterized by hypoxemia and diffuse lung injury leading to increased vascular permeability and loss of aerated lung tissue (Matthay et al. 2012). The ARDS definition in 2012 postulated that the term ,acute respiratory distress syndrome (ARDS)“" will represent the situation in patient characterized with acute hypoxemia and bilateral infiltrates on chest X-ray, without increased wedge pressure in the pulmonary artery (ARDS Definition Task Force 2012). According to severity of hypoxemia expressed by a ratio between arterial partial pressure of oxygen and fraction of inspired oxygen $\left(\mathrm{PaO}_{2} / \mathrm{FiO}_{2}\right)$ ARDS was divided into mild $\left(\mathrm{PaO}_{2} / \mathrm{FiO}_{2}\right.$ 200-300 $\mathrm{mm} \mathrm{Hg}$, or 26.7-40 kPa), moderate $\left(\mathrm{PaO}_{2} / \mathrm{FiO}_{2}\right.$ $100-200 \mathrm{~mm} \mathrm{Hg}$, or $13.3-26.7 \mathrm{kPa})$, and severe $\left(\mathrm{PaO}_{2} / \mathrm{FiO}_{2}<100 \mathrm{~mm} \mathrm{Hg}\right.$, or $\quad<13.3 \mathrm{kPa}$ ) (ARDS Definition Task Force 2012). For animal studies where respiratory insufficiency is induced artificially and other clinically relevant signs except of hypoxemia cannot be determined, the term ,,acute lung injury (ALI)“ is widely used.

Irrespective of the pulmonary or extrapulmonary 
origin of ARDS, an inflammation plays a significant role in the progression of pathological changes (Matthay et al. 2012). In line with the general concept of acute inflammation (Antonelli and Kushner 2017), polymorphonuclears (PMNs) in ALI/ARDS migrate from the blood to the site of inflammation, i.e. into the alveolar space. Migration of PMNs is necessary for a host defense but excessive PMNs migration can damage the epithelial and endothelial barrier and therefore perpetuate the lung injury. Activated PMNs and fixed lung cells generate high concentrations of cytokines, proteases, reactive oxygen species (ROS) etc., which potentiate further lung cell damage, lung edema production and deterioration of the gas exchange (Matthay et al. 2012, Williams and Chambers 2014, Nosál' et al. 2015).

Phosphodiesterases, a superfamily of intracellular enzymes responsible for hydrolysis of cyclic adenosine and/or guanosine monophosphate (cAMP and cGMP), have emerged as new therapeutic targets with a special attention given to phosphodiesterase type-4 (PDE4). PDE4 is expressed in the immune cells and airway smooth muscle cells and regulates the inflammatory responses (Houslay et al. 2005, Jin et al. 2012). PDE4 inhibition results in accumulation of the intracellular cAMP, activation of protein kinase A (PKA), and subsequent phosphorylation of transcription factors, such as cAMP-response element binding protein (CREB) and activating transcription factor 1 (ATF1) regulating the cell proliferation, differentiation and immune responses (Mayr et al. 2001, Wen et al. 2010).

cAMP is generated from ATP through the action of adenylyl cyclase, whereas PDEs hydrolyze cAMP to its inactive $5^{\prime}$-monophosphate. cAMP as a second messenger regulates cell migration, mitochondrial homeostasis, gene transcription, cell proliferation and cell death (Lefkimmiatis and Zaccolo 2014). Imbalance of cAMP in the inflammatory cells can lead to pathological changes. Therefore, great efforts have been devoted to the discovery and development of PDE4 inhibitors as therapeutical agents. Finding of PDE4 activity in eosinophils, neutrophils and CD4+ lymphocytes has suggested a potential for PDE4 inhibitors in chronic obstructive pulmonary disease (COPD) and asthma (Parikh and Chakraborti 2016, Kawamatawong 2017).

Considering the above-mentioned features of ALI/ARDS and effects of PDE4 inhibitors, PDE4 inhibitors can be of benefit also in ALI/ARDS. Administration of roflumilast or other PDE4 inhibitors enhanced lung functions and suppressed neutrophil- mediated inflammation and microvascular permeability in various models of ALI (de Visser et al. 2008, Schick et al. 2012, Hongyan et al. 2014, Konrad et al. 2015). Our recent article has demonstrated that roflumilast can be effective also in the lavage-induced model of ALI where it significantly improved the respiratory parameters in rabbits (Kosutova et al. 2017). Purpose of this study was to investigate additional effects of roflumilast on the production of pro-inflammatory cytokines, generation of markers of oxidative stress, apoptosis of lung epithelial cells and production of lung edema in the same model of ALI.

\section{Methods}

\section{General design of experiments}

Experiments were performed in accordance with ethical guidelines and were authorized by the local Ethics Committee of Jessenius Faculty of Medicine in Martin and by National Veterinary Board.

In the study, adult New Zealand rabbits of both genders and mean body weight (b.w.) of $2.5 \pm 0.3 \mathrm{~kg}$ were used. Animals were anesthetized with intramuscular tiletamine/zolazepam (15 mg/kg b.w.; Zoletil, Virbac, France) and xylazine ( $5 \mathrm{mg} / \mathrm{kg}$ b.w.; Xylariem, Riemser, Germany), followed by infusion of tiletamine/zolazepam $(10 \mathrm{mg} / \mathrm{kg} / \mathrm{h}$ i.v. $)$. Tracheotomy was performed and catheters were inserted into the femoral artery and right atrium for sampling the blood, and into the femoral vein to administer anesthetics. Animals were given a muscle relaxant (pipecuronium bromide, $0.3 \mathrm{mg} / \mathrm{kg}$ b.w. $/ 30 \mathrm{~min}$; Arduan, Gedeon Richter, Hungary), subjected to ventilator Aura V (Chirana, Slovakia) and were ventilated with following settings: frequency (f) of $40 / \mathrm{min}$, fraction of inspired oxygen $\left(\mathrm{FiO}_{2}\right)$ of 1.0, time of inspiration (Ti) $50 \%$, and tidal volume $\left(\mathrm{V}_{\mathrm{T}}\right)<6 \mathrm{ml} / \mathrm{kg}$ b.w. After $15 \mathrm{~min}$ of stabilization, respiratory parameters were recorded and blood samples for analysis of blood gases (RapidLab 348, Siemens, Germany) and estimation of total and differential white blood cell (WBC) counts were taken. One group of healthy ventilated animals served as controls ( $\mathrm{C}$ group, $\mathrm{n}=6$ ). In other animals, lung injury was induced by a repetitive lung lavage with $0.9 \%$ saline $\left(30 \mathrm{ml} / \mathrm{kg}\right.$ b.w., $\left.37^{\circ} \mathrm{C}\right)$ which was instilled into the endotracheal cannula in semi-upright right and left lateral positions of the animal and was immediately suctioned by a suction device. Lavage was performed 6-12 times, until $\mathrm{PaO}_{2}$ decreased to $<26.7 \mathrm{kPa}$ in $\mathrm{FiO}_{2} \quad 1.0$ in 2 measurements at 5 and $15 \mathrm{~min}$ after the lavage. When 
the criteria for the ALI model were full-filled, animals were treated with roflumilast i.v. (Roflumilast, SigmaAldrich, $1 \mathrm{mg} / \mathrm{kg}$ b.w.; A+R group, $\mathrm{n}=8$ ), or were left without therapy (A group, $n=8$ ). All animals were oxygen-ventilated $\left(\mathrm{FiO}_{2} \quad 1.0\right.$, frequency $40 / \mathrm{min}$, $\mathrm{V}_{\mathrm{T}}<6 \mathrm{ml} / \mathrm{kg}$ b.w.) for $4 \mathrm{~h}$ after administration of the treatment and were overdosed by anesthetics at the end of experiment.

Cell analysis in the bronchoalveolar lavage fluid (BALF) and in the blood

After overdosing the animal, lungs and trachea were excised. The left lung was lavaged with saline $\left(0.9 \% \mathrm{NaCl}, 37^{\circ} \mathrm{C}, 3 \times 10 \mathrm{ml} / \mathrm{kg}\right.$ b.w. $)$. Total numbers of cells in the BALF were determined by automated cell counter Countess $^{\mathrm{TM}}$ (Invitrogen, USA) and expressed in absolute values $\left(\mathrm{x} 10^{5} / \mathrm{ml}\right)$. Then, the BALF was centrifuged at $1,500 \mathrm{rpm}$ for $15 \mathrm{~min}$. Differential counts of cells in the BALF sediment were evaluated microscopically after staining by May-Grünwald/GiemsaRomanowski and expressed in percents (\%).

Sample of the arterial blood for counting WBC was taken $4 \mathrm{~h}$ after the treatment. Total WBC count was determined microscopically in a counting chamber after staining by Türck and expressed in absolute values (x $\left.10^{6} / \mathrm{ml}\right)$. Differential WBC count was estimated microscopically after staining by May-Grünwald/GiemsaRomanowski and expressed in percents (\%).

\section{Determination of markers of inflammation and oxidative damage}

Arterial blood taken at the end of experiment was centrifuged $\left(3,000 \mathrm{rpm}, 15 \mathrm{~min}, 4^{\circ} \mathrm{C}\right)$ and plasma was stored at $-70^{\circ} \mathrm{C}$ until the analysis was performed. Samples of the right lung tissue were taken and prepared for additional biochemical and immunohistological analyses.

\section{Preparation of the lung tissue homogenate.}

Concentrations of cytokines and oxidative modification products were determined in $10 \%$ (weight/volume) lung homogenate prepared using $0.1 \mathrm{M}$ ice-cold phosphate buffer (PBS, pH 7.4) by Polytron homogenizer PT 1200 E (5-times for 25 s, 1,200 rpm; Kinematica AG, Switzerland). Homogenates were 3-times freezed and centrifuged $(12,000 \mathrm{rpm}, 15 \mathrm{~min}$, $\left.4{ }^{\circ} \mathrm{C}\right)$. Final supernatants were then stored at $-70{ }^{\circ} \mathrm{C}$ until the analysis was performed.
Measurement of markers of inflammation and oxidative damage by enzyme-linked immunosorbent assay (ELISA)

Oxidative damage to proteins was determined using OxiSelectTM Nitrotyrosine ELISA Kit (Cell Biolabs Inc., USA) and expressed as a concentration of 3-nitrotyrosine in nanomoles (nM 3NT). Oxidative damage to lipids expressed as concentration of thiobarbituric acid reacting substances (TBARS) was determined by OxiSelectTM TBARS Assay Kit (Cell Biolabs Inc., USA), and was shown as a concentration of malondialdehyde in micromoles ( $\mu \mathrm{M}$ MDA). Concentrations of TNF $\alpha$, IL-6, IL- 8 were quantified in duplicate using rabbit-specific ELISA kits (USCN Life Science Inc., China) according to the manufacturer's instructions and expressed in $\mathrm{pg} / \mathrm{ml}$.

\section{Protein content in BALF}

Measurement of total protein content in BALF was performed by colorimetric method according to Bradford (1976) with bovine serum albumin (BSA) as a standard. Analysis was performed in the sample of BALF taken at the end of experiment $(4 \mathrm{~h}$ after the therapy), and results were expressed in $\mu \mathrm{g} / \mathrm{ml}$.

\section{Apoptosis Assay}

In situ labeling of DNA strand breaks by TUNEL method

The lungs were immersed in $4 \%$ formalin solution. After paraffin embedding, $4 \mu \mathrm{m}$ thick slides were cut on microtome followed by deparaffinization and pretreatment with proteinase $\mathrm{K}$. The tissue sections were further processed by DeadEnd ${ }^{\mathrm{TM}}$ Colorimetric TUNEL System (Promega, USA). This assay labels the fragmented DNA of apoptotic cells. Biotinylated nucleotide is incorporated at the $3^{\prime}-\mathrm{OH}$ DNA ends using the Terminal Deoxynucleotidyl Transferase, Recombinant, (rTdT) enzyme. Horseradish peroxidaselabeled streptavidin (Streptavidin HRP) is then bound to these biotinylated nucleotides. For detection of nucleotides and blocking endogenous peroxidases, the sections were incubated with $0.3 \% \mathrm{H}_{2} \mathrm{O}_{2}$ solution. Color of sections was developed after incubation with diaminobenzidine, DAB-chromogen solution. The sections were then counterstained with Mayer's hematoxylin and mounted with Permount (Fisher, USA). The slides were viewed with microscope (BX41, Olympus, Japan). The image capture was performed with Quick Photo Micro software, version 2.2 (Olympus, Japan). The apoptotic index was calculated as 
a percentage of TUNEL immunoreactive (TUNEL-IR) dark brown stained nuclei in a total 100 nuclei randomly counted from three sites within each section.

\section{Immunohistochemical investigation of activated caspase-3}

After deparaffinization, revitalization and rehydratation, the tissue slides were treated with $3 \%$ $\mathrm{H}_{2} \mathrm{O}_{2}$ solution for $10 \mathrm{~min}$ for blocking endogenous peroxidases. Washing with Tris buffer was used after each handling step. The sections were incubated with the primary antibody rabbit anti-caspase 3 (1:500; Bioss, Woburn, MA, USA) for $30 \mathrm{~min}$ at room temperature. The specimen was then incubated by sequential $10 \mathrm{~min}$ incubation with biotinylated anti-rabbit secondary antibody and peroxidase-labelled streptavidin conjugated to HRP (DAKO LSAB®2 System-HRP; Dako, Glostrup, Denmark). Color of sections was developed after incubation with DAB-chromogen solution (Dako). The sections were counterstained with Mayer's hematoxylin and mounted with an Entellan (Merck, USA). The slides were viewed with microscope (BX41, Olympus, Japan). The image capture was performed with Quick Photo Micro software, version 2.2 (Olympus, Japan). The density of activated caspase 3 immunoreactive cells (dark-brown cytoplasm; caspase 3-IR) was measured randomly from three sites within each section and was calculated as the total numbers of caspase 3-IR cells in the field.

\section{Statistical analysis}

Statistical analysis was performed using GraphPad Prism version 5.1 for Windows (GraphPad Software, USA). Statistical differences between the groups were determined by Analysis of variance (ANOVA) with Bonferroni post hoc test or with KruskalWallis test. Data are presented as means $\pm \mathrm{SEM}$. A value of $p<0.05$ was considered significant.

\section{Results}

\section{Cell counts in the BALF and in the blood}

The total count of circulating WBC at $4 \mathrm{~h}$ Th decreased in A vs. C group ( $\mathrm{p}<0.05$; Table 1$)$, and percentage of blood neutrophils decreased and percentage of lymphocytes increased in A vs. C group (for both $\mathrm{p}<0.001$; Table 1). Roflumilast elevated percentage of neutrophils and decreased percentage of lymphocytes compared to A group (A+R vs. A, for both $\mathrm{p}<0.001$; Table 1).
Induction of ALI model increased the total cell count in BALF compared with the control (A vs. C $p<0.01$, while roflumilast decreased the total number of cells in BALF (A+R vs. A $p<0.05$; Table 1). Differential analysis of cell types showed that the percentages of neutrophils increased and percentages of monocytesmacrophages decreased in A vs. C group (for both $\mathrm{p}<0.001$; Table 1), and roflumilast increased percentage of monocytes-macrophages and decreased neutrophils in BALF compared with A group (A+R vs. A, for both $\mathrm{p}<0.001$; Table 1).

\section{Cytokine production in the lung tissue and plasma}

Concentrations of cytokines increased in A vs. C group (TNF $\alpha$ in lung $p<0.01$, in plasma $p<0.05$, IL-8 in lung $\mathrm{p}<0.01$, in plasma $\mathrm{p}<0.01$, and IL- 6 in lung $\mathrm{p}<0.05$, in plasma $\mathrm{p}<0.01$ ). Roflumilast therapy reduced the cytokines concentrations compared to untreated A group in both lung tissue (for $\mathrm{A}+\mathrm{R}$ vs. $\mathrm{A}$ : TNF $\alpha \mathrm{p}<0.001$, IL-8 $\mathrm{p}<0.01$, IL-6 $\mathrm{p}<0.01$ ) and plasma (for $\mathrm{A}+\mathrm{R}$ vs. $\mathrm{A}$ : TNF $\alpha$ $p<0.01$, IL-8 $p<0.01$, IL-6 $p<0.05$; Fig. 1).

\section{Oxidative modifications in the lung tissue and plasma}

Oxidative damage to proteins in the lung and plasma expressed as 3-nitrotyrosine (3NT) increased in A vs. $C$ group (in lung $p<0.05$, in plasma $p<0.05$ ), and decreased in the lung after roflumilast treatment $(\mathrm{A}+\mathrm{R}$ vs. A $p<0.05$; Fig. 2). Oxidative damage to lipids expressed by formation of malondialdehyde was higher in A vs. C group (in lung $\mathrm{p}<0.01$, in plasma $\mathrm{p}<0.001$ ). Concentration of MDA in the treated group decreased compared to the untreated group ( $\mathrm{A}+\mathrm{R}$ vs. $\mathrm{A}$ in lung $\mathrm{p}<0.001$, in plasma $\mathrm{p}<0.001$, Fig. 2).

\section{Protein content in BALF}

Repetitive saline lung lavage increased lung fluid accumulation in A vs. C group as indicated by increased protein content in BALF $(0.62 \pm 0.04 \mu \mathrm{g} / \mathrm{ml}$ for $\mathrm{C}$ and $1.40 \pm 0.06 \mu \mathrm{g} / \mathrm{ml}$ for $\mathrm{A} ; \mathrm{p}<0.001)$. Roflumilast treatment reduced protein content in BALF $(1.16 \pm 0.07 \mu \mathrm{g} / \mathrm{ml}$ for $\mathrm{A}+\mathrm{R})$ compared to A group $(\mathrm{A}+\mathrm{R}$ vs. A, for both $\mathrm{p}<0.05$ ).

\section{Apoptosis of the lung epithelial cells}

Apoptotic index (i.e. percentage of TUNEL immunoreactive cells) elevated in A vs. $C$ group $(p<0.01)$ and decreased after roflumilast treatment $(\mathrm{A}+\mathrm{R}$ vs. A $p<0.05$; Fig. 3).

Similarly, number of caspase-3 immunoreactive 
cells in the lung increased in A vs. C group $(p<0.05)$, while roflumilast decreased the number of caspase- 3 immunoreactive cells compared to untreated ALI animals $(\mathrm{p}<0.001$; Fig. 4).

\section{Discussion}

Disturbance of the alveolar-capillary barrier in ALI/ARDS is associated with severe inflammatory changes. Our study demonstrated that intravenous administration of PDE4 inhibitor roflumilast has a potential to effectively suppress a generation of pro-inflammatory cytokines, reduce an oxidation of lipids and proteins and mitigate an apoptosis of the lung epithelial cells and thereby decrease a lung edema formation.

The PDE4 inhibitors have attracted a considerable attention in the last two decades because of their potential use in pulmonary inflammatory diseases (Jeffery 2005, de Visser et al. 2008, Jin et al. 2012, Matera et al. 2014). PDE4 enzymes hydrolyze cAMP and are encoded by four distinct genes (PDE4A--PDE4D). Their isoforms show specific cell-type patterns of expression and distribution, and they play regulatory

Table 1. Total count of leukocytes (expressed as absolute value $\times 10^{6} / \mathrm{ml}$ ) and percentage of differential leukocyte count (expressed in $\%$ ) in the arterial blood before (basal value, BV) and at $4 \mathrm{~h}$ after the therapy (Th); and total count of cells (expressed as absolute value $\times 10^{5} / \mathrm{ml}$ ) and percentage of differential cell count in the bronchoalveolar lavage fluid (BALF) in the healthy ventilated controls (C), untreated group with ALI $(A)$, and ALI group treated with PDE4 inhibitor roflumilast (A+R).

\section{Arterial blood}

C

Total count of blood leukocytes (x $\left.10^{6} / \mathrm{ml}\right)$

$\begin{array}{cccc}\mathrm{BV} & 1.7 \pm 0.2 & 1.6 \pm 0.1 & 1.8 \pm 0.2 \\ 4 \mathrm{~h} \mathrm{Th} & 2.3 \pm 0.5 & 1.1 \pm 0.2^{*} & 1.7 \pm 0.1\end{array}$

Differential count of blood leukocytes (\%)

\begin{tabular}{|c|c|c|c|c|}
\hline \multirow[t]{2}{*}{$\mathrm{Neu}$} & BV & $3.6 \pm 0.8$ & $1.3 \pm 0.3$ & $1.3 \pm 0.3$ \\
\hline & $4 \mathrm{~h} \mathrm{Th}$ & $33.3 \pm 4.5$ & $19.6 \pm 2.1^{* * *}$ & $30.7 \pm 3.0^{\# \# \#}$ \\
\hline \multirow[t]{2}{*}{ Lym } & BV & $95.0 \pm 1.0$ & $97.0 \pm 0.4$ & $96.7 \pm 0.7$ \\
\hline & $4 \mathrm{~h} \mathrm{Th}$ & $65.1 \pm 4.4$ & $79.5 \pm 2.0^{* * *}$ & $68.4 \pm 3.1^{\# \# \#}$ \\
\hline \multirow[t]{2}{*}{ Mo } & BV & $0.9 \pm 0.1$ & $0.9 \pm 0.1$ & $0.8 \pm 0.1$ \\
\hline & $4 \mathrm{~h} \mathrm{Th}$ & $1.0 \pm 0.2$ & $0.8 \pm 0.1$ & $0.6 \pm 0.1$ \\
\hline \multirow[t]{2}{*}{ Eos } & BV & $0.5 \pm 0.1$ & $0.7 \pm 0.4$ & $1.2 \pm 0.4$ \\
\hline & $4 \mathrm{~h} \mathrm{Th}$ & $0.7 \pm 0.2$ & $0.3 \pm 0.2$ & $0.2 \pm 0.1$ \\
\hline
\end{tabular}

\section{Bronchoalveolar lavage fluid (BALF)}

\begin{tabular}{|c|c|c|c|c|}
\hline & & $\mathbf{C}$ & $\mathbf{A}$ & $\mathbf{A}+\mathbf{R}$ \\
\hline \multicolumn{5}{|c|}{ Total count of cells in BALF (x 105/ml) } \\
\hline & $4 \mathrm{~h} \mathrm{Th}$ & $3.5 \pm 0.5$ & $21.6 \pm 8.8^{* *}$ & $3.8 \pm 0.8^{\#}$ \\
\hline \multicolumn{5}{|c|}{ Differential count of cells in BALF (\%) } \\
\hline \multirow[t]{2}{*}{$\mathrm{Neu}$} & BV & $1.0 \pm 0.2$ & $1.5 \pm 0.2$ & $2.7 \pm 0.7$ \\
\hline & $4 \mathrm{~h} \mathrm{Th}$ & $3.0 \pm 0.6$ & $76.5 \pm 5.4 * * *$ & $42.2 \pm 9.9^{\# \# \#}$ \\
\hline \multirow[t]{2}{*}{$M o-M a$} & BV & $98.7 \pm 0.4$ & $98.2 \pm 0.2$ & $96.8 \pm 0.8$ \\
\hline & $4 \mathrm{~h} \mathrm{Th}$ & $96.2 \pm 0.7$ & $20.4 \pm 5.1 * * *$ & $56.4 \pm 9.9^{\# \# \#}$ \\
\hline \multirow[t]{2}{*}{ Eos } & BV & $0.4 \pm 0.2$ & $0.3 \pm 0.0$ & $0.4 \pm 0.1$ \\
\hline & $4 \mathrm{~h} \mathrm{Th}$ & $0.8 \pm 0.2$ & $3.1 \pm 0.8$ & $1.4 \pm 0.2$ \\
\hline
\end{tabular}

Blood: Neu: neutrophils, Lym: lymphocytes, Mo: monocytes, Eos: eosinophils; BALF: Neu: neutrophils, Mo-Ma: monocytesmacrophages, Eos: eosinophils. Data are presented as means \pm SEM. Statistical comparisons: A vs. C: $* p<0.05, * * p<0.01$, *** $\mathrm{p}<0.001 ; \mathrm{A}+\mathrm{R}$ vs. A: ${ }^{\#} \mathrm{p}<0.05,{ }^{\prime \prime \prime} \mathrm{p}<0.001$. 

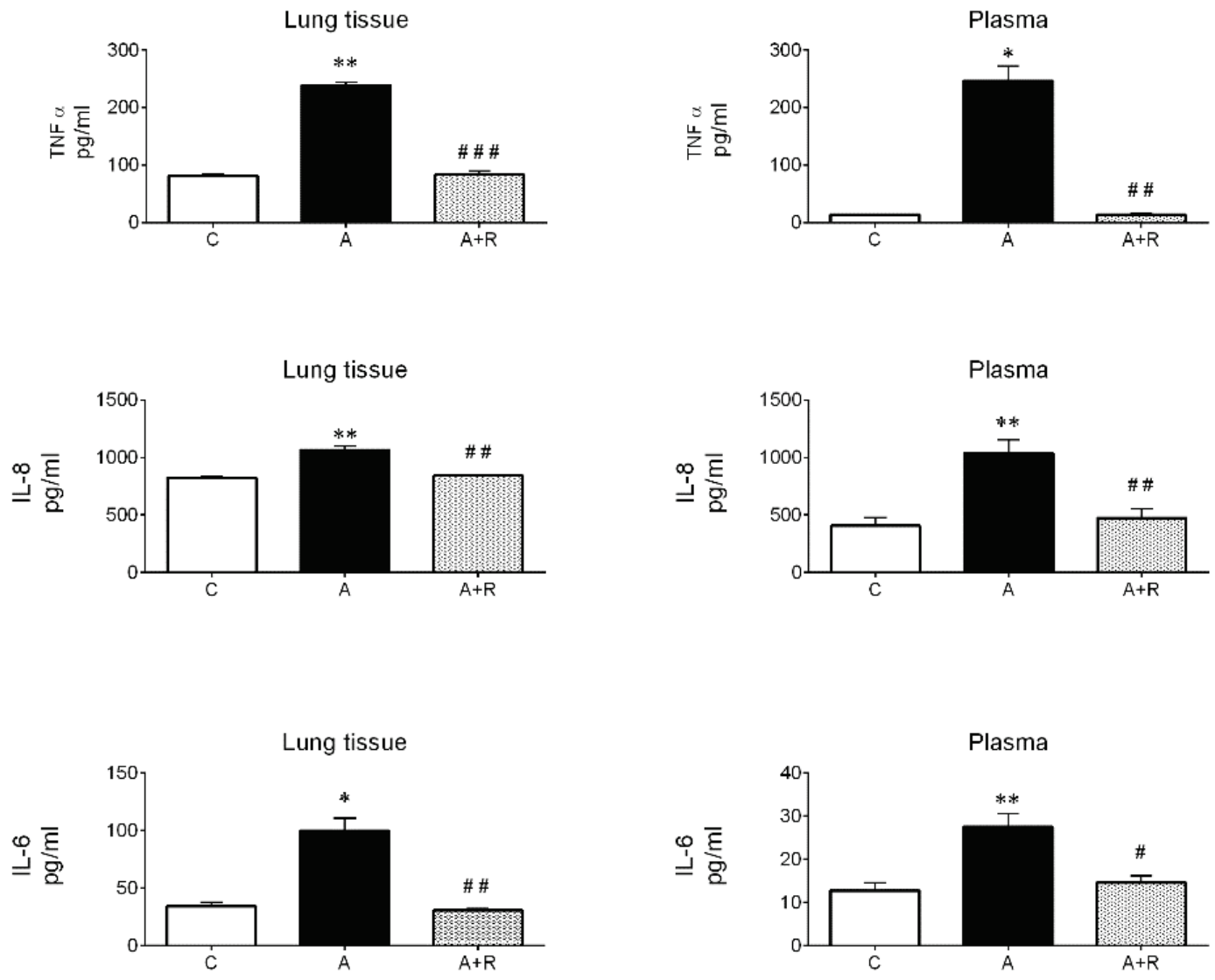

Fig. 1. Concentrations of TNFa, IL-8, and IL-6 in the lung tissue and plasma measured using ELISA method (expressed in $\mathrm{pg} / \mathrm{ml}$ ) in the ventilated controls $(C)$, untreated group with ALI $(A)$, and ALI group treated with PDE4 inhibitor roflumilast $(A+R)$. Statistical comparisons: A vs. C: $* p<0.05, * * p<0.01 ; A+R$ vs. A: ${ }^{*} p<0.05,{ }^{\#} p<0.01,{ }^{\#} p<0.001$. Statistical comparisons: A vs. C: $* p<0.05$, ${ }^{* *} p<0.01 ; A+R$ vs. A: ${ }^{p} p<0.05,{ }^{\#} p<0.01,{ }^{\# \#} p<0.001$.

\section{Protein oxidation}
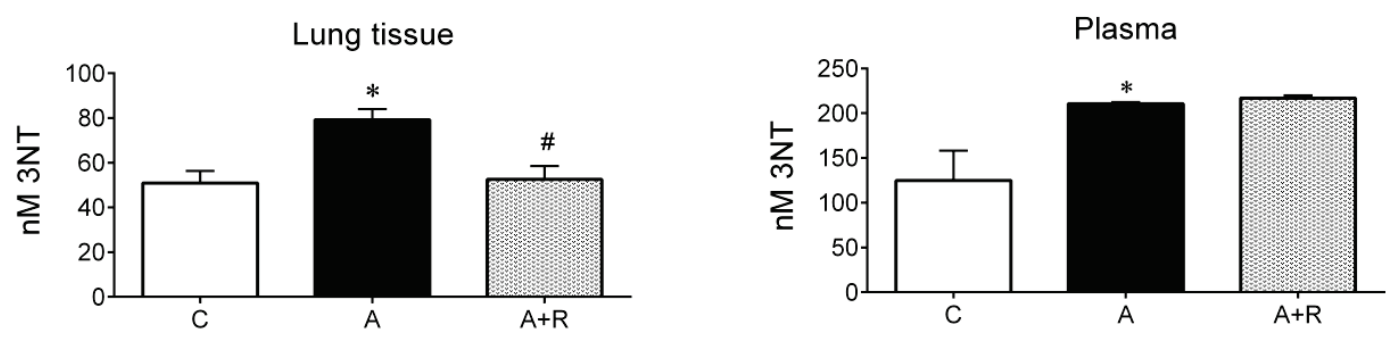

\section{Lipid oxidation}
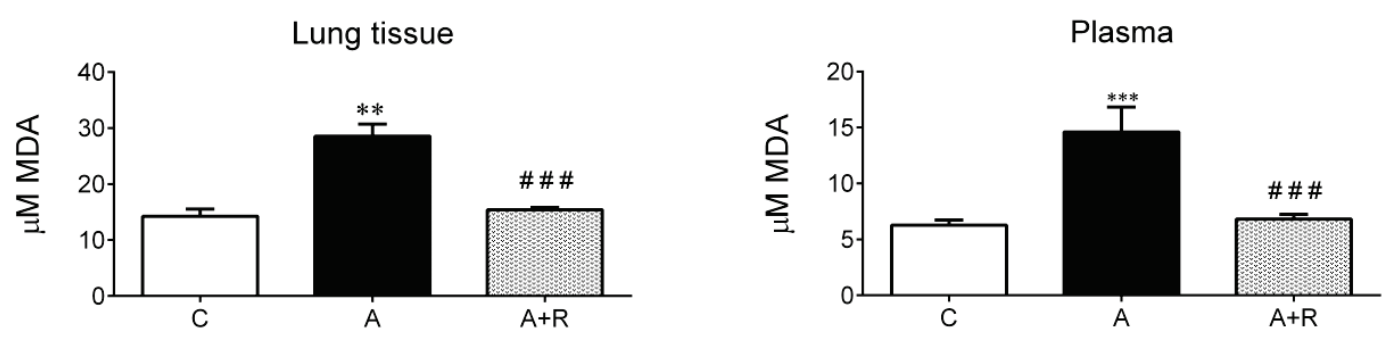

Fig. 2. Oxidative modifications in the lung tissue and plasma of the ventilated controls (C), untreated group with ALI (A), and ALI group treated with PDE4 inhibitor roflumilast $(A+R)$. Marker of protein oxidation 3-nitrotyrosine is expressed in nanomole concentration (nM 3NT) and marker of lipid oxidation thiobarbituric acid-reactive substances (TBARS) is expressed in micromole concentration of malondialdehyde ( $\mu \mathrm{mol}$ MDA). Statistical comparisons: A vs. C: $* p<0.05, * * p<0.01, * * * p<0.001 ; A+R$ vs. A: ${ }^{*} p<0.05,{ }^{\#} p<0.001$. 

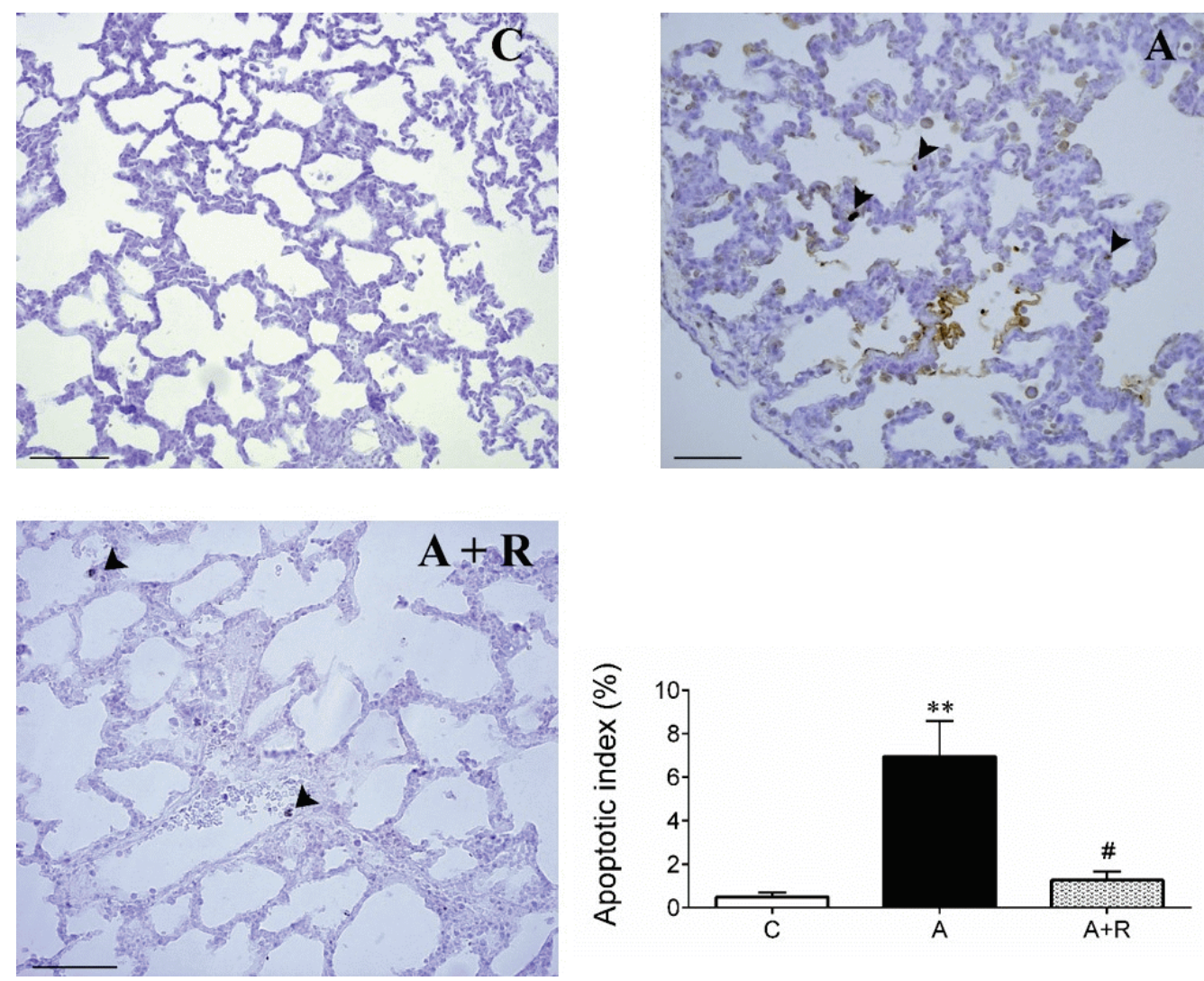

Fig. 3. Percentage of terminal deoxynucleotidyl transferase-mediated dUTP nick end labeling (TUNEL)-positive cells in the alveolar epithelium of the ventilated controls (C), untreated group with ALI (A), and ALI group treated with PDE4 inhibitor roflumilast (A+R). Arrowheads represent TUNEL-positive cells. Statistical comparisons: A vs. C: $* * p<0.01 ; A+R$ vs. A: ${ }^{*} p<0.05$.
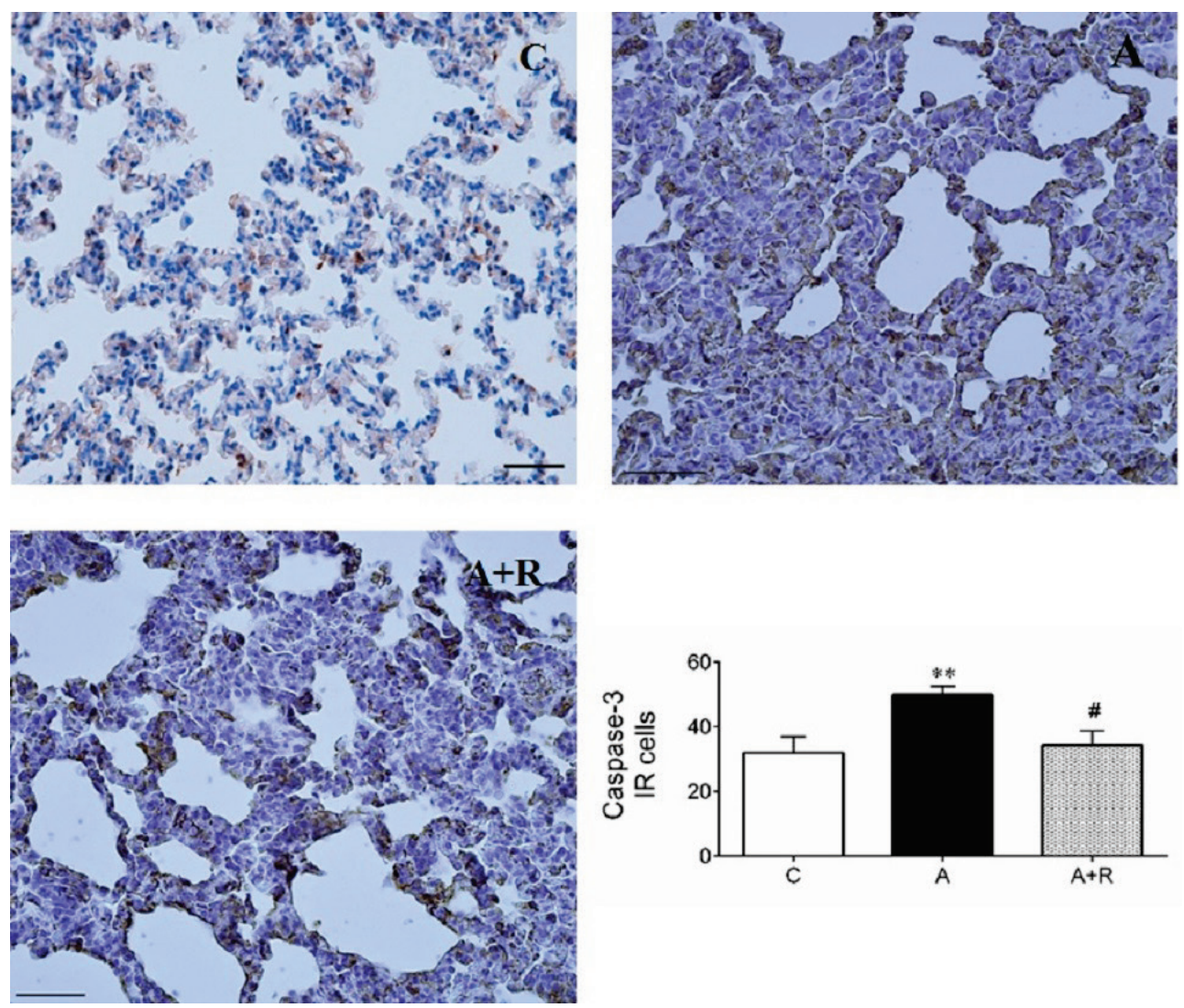

Fig. 4. Number of caspase- 3 positive cells in the alveolar epithelium of the ventilated controls (C), untreated group with ALI (A), and ALI group treated with PDE4 inhibitor roflumilast $(A+R)$. Statistical comparisons: $A$ vs. $C: * * p<0.01 ; A+R$ vs. $A:{ }^{*} p<0.05$. 
roles in many cell types and tissues including leukocytes, airway and vascular smooth muscle, endothelium and brain (Houslay et al. 2005). Besides well-established use of PDE4 inhibitors in chronic inflammatory lung diseases, such as COPD and bronchial asthma (Parikh and Chakraborti 2016, Kawamatawong 2017), the PDE4 inhibitors can exert their positive effects also in acute damage of the lung. Long biological halftime of roflumilast (and its metabolization to active metabolite roflumilast $\mathrm{N}$-oxide) allows to deliver a single dose, without necessity of repetitive administration to keep an appropriate plasma level. If roflumilast is delivered intravenously, therapeutic levels can be reached immediately, and effects on the inflammatory cells and other cells and tissues could be detectable within several hours, as it was documented by our results. Rapid positive effects of roflumilast or other PDE4 inhibitors on the lung functions, inflammation and microvascular permeability were also observed in various models of ALI (de Visser et al. 2008, Schick et al. 2012, Konrad et al. 2015).

In this study, effects of roflumilast were investigated in the saline-lavage induced model of ALI. In ALI/ARDS, recruitment of neutrophils with their subsequent activation and generation of bioactive substances and ROS is related to plasma leakage, degradation of surfactant proteins, epithelial cell apoptosis (Pham 2006), tissue injury (Grommes and Soehnlein 2011) and finally to deterioration of oxygenation. In our study, depletion of pulmonary surfactant due to saline lung lavage caused an acute pulmonary neutrophilia, as demonstrated by increased numbers of neutrophils in BALF. This finding is consistent with our recently published data (Mokra et al. 2016) as well as with findings of other authors (Noda et al. 2003, Waragai et al. 2007). Roflumilast in this study diminished the lung infiltration by neutrophils. Reduced counts of neutrophils in the lung after the treatment with PDE4 inhibitors were also demonstrated in other models of ALI (Häfner and Germann 2000, de Visser et al. 2008, Kubo et al. 2012).

Pro-inflammatory cytokines TNF $\alpha$, IL-6 and IL-8 are used as biomarkers of an early phase of ALI/ARDS (Cross and Matthay 2011, Mokra and Kosutova 2015). Herein, concentrations of TNF $\alpha$, IL-6 and IL- 8 increased in the untreated ALI group compared with the control group what is consistent with the previous studies of our research group (Kosutova et al. 2016, Mokra et al. 2016) and the studies of other authors
(Noda et al. 2003, Waragai et al. 2007). After administration of roflumilast, the concentrations of IL-6, IL-8 and TNF $\alpha$ were markedly reduced in both lung tissue and plasma. In agreement with our findings, PDE4 inhibitors alleviated lung inflammation also in other models of lung injury (de Visser et al. 2008, Chang et al. 2012).

In ALI/ARDS, breakdown of endothelial barrier functions leads to a massive increase in vascular permeability (Lee and Slutsky 2010, Otáhal et al. 2016). The endothelial barrier is sealed by tight and adherens junctions, both of which are targeted during acute inflammation, what results in the formation of intercellular gaps with consecutive extravasation of fluid (Spindler et al. 2010). In this study, repetitive saline lavage of the lung caused a leak of proteinaceous liquid through an alveolar-capillary barrier as it was expressed by elevated protein content in BALF, whereas it was lowered by roflumilast. Inhibition of microvascular leakage and reduced fluid loss in the roflumilast-treated animals were also demonstrated in other studies (de Visser et al. 2008, Chang et al. 2012). It can be presumed that an increase in CAMP enhances stability of intercellular junctions by PKA- or EPAC/Rap1dependent activation of small GTPase Rac1 and thereby prevents an increased endothelial permeability (Schlegel and Waschke 2009, Spindler et al. 2010).

$\mathrm{ALI} / \mathrm{ARDS}$ is associated with overproduction of ROS by inflammatory and parenchymal cells. Expression of pro-inflammatory genes can multiply the oxidative stress, and vice versa, inflammatory cells may trigger ROS overproduction (Tasaka et al. 2008, Matthay et al. 2012). In our study, protein nitrosylation (expressed by $3 \mathrm{NT}$ ) and lipid peroxidation (expressed by MDA) were significantly increased in the lung tissue and plasma in ALI group compared to controls. The administration of roflumilast effectively inhibited lipid peroxidation in the lung and plasma, and reduced oxidative damage of proteins in the lung tissue.

The mentioned pro-inflammatory factors contribute to a dysbalance of the lung cell apoptosis. Apoptosis is a main mechanism for elimination of unnecessary cells during development and homeostasis in normal tissue, however, dysfunction of the apoptotic system leads to a variety of diseases. In ALI/ARDS, the apoptosis of neutrophils is delayed what causes their prolonged persistence and detrimental effects in the lung tissue, while the apoptosis of epithelial and endothelial cells is increased (Galani et al. 2010). 
Apoptosis can be initiated by two alternative pathways: an extrinsic pathway triggered by binding of a death ligand (e.g. Fas/FasL ligand or TNF $\alpha$ ) to cell surface death receptors, and an intrinsic pathway induced in response to cytokines, action of hypoxia or oxidants. Both pathways converge into activating effector caspase$3,-6$ or -7 , which are responsible for cell alterations and execution of cell death (Lu et al. 2005). In ALI/ARDS, both pathways are activated. In this study, roflumilast inhibited the apoptosis of epithelial cells, as indicated by lower numbers of apoptotic cells detected by TUNEL methods and decreased activation of caspase- 3 in the epithelial cells and diminished number of caspase-3-IR cells in the lung tissue.

In conclusion, intravenous administration of selective PDE4 inhibitor roflumilast reduced PMNs migration into the lung and their activation, mitigated inflammation and apoptosis, and decreased lung edema formation in rabbits with saline lung lavage-induced ALI.

\section{Conflict of Interest}

There is no conflict of interest.

\section{Acknowledgements}

The study was supported by projects APVV-0435-11, APVV-15-0075, VEGA 1/0356/18; and by projects „Biomedical Center Martin“, ITMS 26220220187 and CEPV II, ITMS 26220120016, co-financed from EU sources.

\section{References}

ANTONELLI M, KUSHNER I: It's time to redefine inflammation. FASEB J 31: 1787-1791, 2017.

ARDS DEFINITION TASK FORCE, RANIERI VM, RUBENFELD GD, THOMPSON BT, FERGUSON ND, CALDWELL E, FAN E, CAMPOROTA L, SLUTSKY AS: Acute respiratory distress syndrome: the Berlin definition. JAMA 307: 2526-2533, 2012.

BRADFORD MM: A rapid and sensitive method for the quantitation of microgram quantities of protein utilizing the principle of protein-dye binding. Anal Biochem 72: 248-254, 1976.

CROSS LJ, MATTHAY MA: Biomarkers in acute lung injury: insights into the pathogenesis of acute lung injury. Crit Care Clin 27: 355-377, 2011.

DE VISSER YP, WALTHER FJ, LAGHMANI EH, VAN WIJNGAARDEN S, NIEUWLAND K, WAGENAAR GT: Phosphodiesterase-4 inhibition attenuates pulmonary inflammation in neonatal lung injury. Eur Respir $J$ 31: 633-644, 2008.

GALANI V, TATSAKI E, BAI M, KITSOULIS P, LEKKA M, NAKOS G, KANAVAROS P: The role of apoptosis in the pathophysiology of Acute Respiratory Distress Syndrome (ARDS): an up-to-date cell-specific review. Pathol Res Pract 206: 145-150, 2010.

GROMMES J, SOEHNLEIN O: Contribution of neutrophils to acute lung injury. Mol Med 17: 293-307, 2011.

HÄFNER D, GERMANN PG: Additive effects of phosphodiesterase-4 inhibition on effects of rSP-C surfactant. Am J Respir Crit Care Med 161: 1495-1500, 2000.

HOUSLAY MD, SCHAFER P, ZHANG KY: Keynote review: phosphodiesterase-4 as a therapeutic target. Drug Discov Today 10: 1503-1519, 2005.

CHANG W, CHEN J, SCHLUETER CF, RANDO RJ, PATHAK YV, HOYLE GW: Inhibition of chlorine-induced lung injury by the type 4 phosphodiesterase inhibitor rolipram. Toxicol Appl Pharmacol 263: 251-258, 2012.

JEFFERY P: Phosphodiesterase 4-selective inhibition: novel therapy for the inflammation of COPD. Pulm Pharmacol Ther 18: 9-17, 2005.

JIN SL, DING SL, LIN SC: Phosphodiesterase 4 and its inhibitors in inflammatory diseases. Chang Gung Med J 35: 197-210, 2012.

KAWAMATAWONG T: Roles of roflumilast, a selective phosphodiesterase 4 inhibitor, in airway diseases. $J$ Thorac Dis 9: 1144-1154, 2017.

KONRAD FM, BURY A, SCHICK MA, NGAMSRI KC, REUTERSHAN J: The unrecognized effects of phosphodiesterase 4 on epithelial cells in pulmonary inflammation. PLoS One 10: e0121725, 2015. 
KOSUTOVA P, MIKOLKA P, BALENTOVA S, ADAMKOV M, KOLOMAZNIK M, CALKOVSKA A, MOKRA D: Intravenous dexamethasone attenuated inflammation and influenced apoptosis of lung cells in an experimental model of acute lung injury. Physiol Res 65 (Suppl 5): S663-S672, 2016.

KOSUTOVA P, MIKOLKA P, KOLOMAZNIK M, REZAKOVA S, CALKOVSKA A, MOKRA D: Effects of roflumilast, a phosphodiesterase-4 inhibitor, on the lung functions in a saline lavage-induced model of acute lung injury. Physiol Res 66 (Suppl 2): S237-S245, 2017.

KUBO S, KOBAYASHI M, IWATA M, MIYATA K, TAKAHASHI K, SHIMIZU Y: Anti-neutrophilic inflammatory activity of ASP3258, a novel phosphodiesterase type 4 inhibitor. Int Immunopharmacol 12: 59-63, 2012.

LEE WL, SLUTSKY AS: Sepsis and endothelial permeability. N Engl J Med 363: 689-691, 2010.

LEFKIMMIATIS K, ZACCOLO M: cAMP signaling in subcellular compartments. Pharmacol Ther 143: 295-304, 2014.

LU Q, HARRINGTON EO, ROUNDS S: Apoptosis and lung injury. Keio J Med 54: 184-189, 2005.

MATERA MG, PAGE C, CAZZOLA M: PDE inhibitors currently in early clinical trials for the treatment of asthma. Expert Opin Investig Drugs 23: 1267-1275, 2014.

MATTHAY MA, WARE LB, ZIMMERMAN GA: The acute respiratory distress syndrome. J Clin Invest 122: 2731-2740, 2012.

MAYR BM, CANETTIERI G, MONTMINY MR: Distinct effects of cAMP and mitogenic signals on CREB-binding protein recruitment impart specificity to target gene activation via CREB. Proc Natl Acad Sci USA 98: 10936-10941, 2001.

MOKRA D, KOSUTOVA P, BALENTOVA S, ADAMKOV M, MIKOLKA P, MOKRY J, ANTOSOVA M, CALKOVSKA A: Effects of budesonide on the lung functions, inflammation and apoptosis in a saline-lavage model of acute lung injury. J Physiol Pharmacol 67: 919-932, 2016.

MOKRA D, KOSUTOVA P: Biomarkers in acute lung injury. Resp Physiol Neurobiol 209: 52-58, 2015.

NODA E, HOSHINA H, WATANABE H, KAWANO T: Production of TNF-alpha by polymorphonuclear leukocytes during mechanical ventilation in the surfactant-depleted rabbit lung. Pediatr Pulmonol 36: 475-481, 2003.

NOSÁl' R, DRÁBIKOVÁ K, JANČINOVÁ V, MAČIČKOVÁ T, PEČIVOVÁ J, PEREČKO T, HARMATHA J, ŠMIDRKAL J: On the pharmacology of oxidative burst of human neutrophils. Physiol Res 64 (Suppl 4): S445-S452, 2015.

OTÁHAL M, MLČEK M, VÍTKOVÁ I, KITTNAR O: A novel experimental model of acute respiratory distress syndrome syndrome in pig. Physiol Res 65 (Suppl 5): S643-S651, 2016.

PARIKH N, CHAKRABORTI AK: Phosphodiesterase 4 (PDE4) inhibitors in the treatment of COPD: promising drug candidates and future directions. Curr Med Chem 23: 129-141, 2016.

PHAM CT: Neutrophil serine proteases: Specific regulators of inflammation. Nat Rev Immunol 6: 541-550, 2006.

SCHICK MA, WUNDER C, WOLLBORN J, ROEWER N, WASCHKE J, GERMER CT, SCHLEGEL N: Phosphodiesterase-4 inhibition as a therapeutic approach to treat capillary leakage in systemic inflammation. J Physiol 590: 2693-2708, 2012.

SCHLEGEL N, WASCHKE J: Impaired cAMP and Rac 1 signaling contribute to TNF- $\alpha$-induced endothelial barrier breakdown in microvascular endothelium. Microcirculation 16: 521-533, 2009.

SPINDLER V, SCHLEGEL N, WASCHKE J: Role of GTPases in control of microvascular permeability. Cardiovasc Res 87: 243-253, 2010.

TASAKA S, AMAYA F, HASHIMOTO S, ISHIZAKA A: Roles of oxidants and redox signaling in the pathogenesis of acute respiratory distress syndrome. Antioxid Redox Signal 10: 739-753, 2008.

WARAGAI A, YAMASHITA H, HOSOI K, HOSHINA H, NODA E, YAN K, KAWANO T: High-frequency oscillation (HFO) prevents activation of NF-kappaB found with conventional mechanical ventilation (CMV) in surfactant-depleted rabbit lung. Pediatr Pulmonol 42: 440-445, 2007.

WEN AY, SAKAMOTO KM, MILLER LS: The role of the transcription factor CREB in immune function. J Immunol 185: 6413-6419, 2010.

WILLIAMS AE, CHAMBERS RC: The mercurial nature of neutrophils: still an enigma in ARDS? Am J Physiol Lung Cell Mol Physiol 306: L217-L230, 2014. 